\title{
LIFE CYCLE ASSESSMENT (LCA) AS A TOOL FOR BUSINESS STRATEGY
}

Rodrigo Salvador Federal University of Technology - Paraná (UTFPR), Brazil E-mail: salvador.rodrigors@gmail.com

Antonio Carlos Francisco Federal University of Technology - Paraná (UTFPR), Brazil E-mail: acfrancisco@utfpr.edu.br

Cassiano Moro Piekarski Federal University of Technology - Paraná (UTFPR), Brazil E-mail: cassianopiekarski@gmail.com

Leila Mendes Luz Federal University of Technology - Paraná (UTFPR), Brazil E-mail: leila.mendesdaluz@gmail.com

Submission: $14 / 01 / 2014$ Revision: 28/01/2014

The growing concern about the development of sustainable production systems leads organizations to seek the support of management tools for decision-making. Considering the whole life cycle of the product, the Life Cycle Assessment (LCA) has an important role in this scenario. The objective of this paper is to present, through the theoretical discussion, the role of LCA in strategic planning of the organization. It showed the enormous potential for decision making on the environmental aspect, but also the critical factor in the development shares in the competitive context. The use of LCA can reduce the environmental impacts of the system under study (primary purpose) and guide the range of advantages in the fields of marketing, legislation and environmental labeling, competitive strategies, efficiency resources use of and others.

Keywords: Environmental Strategic Planning; LCA; Life Cycle Assessment. 
ISSN: 2236-269X

DOI: 10.14807/ijmp.v5i3.186

\section{INTRODUCTION}

The planning necessity in an organization, for any business or activity, is growing towards the incessant technological development facing society today. It is not just a differential, the planning necessity is a survival factor to plan and control production processes, or even develop any company activities.

The development of new strategies has been supported by the use of different tools, whether in economic, environmental or social perspective. In environmental context, is evident the use of tools that allow the measurement of the environmental or sustainable performance of different system. In this sense, by corroboration of several studies (BAILIS et al., 2013; CHEN et al., 2012; MANDA; BLOK; PATEL, 2012; GONZÁLEZ-GARCIA, 2012; GUTIÉRREZ et al., 2012; BRIBIÁN, CAPILLA; USÓN, 2011; SANTOS; TENÓRIO, 2010; BENETTO; BECKER; WELFRING, 2009; RIVELA; MOREIRA; FEIJOO, 2007) the Life Cycle Assessment (LCA) is shown as the most comprehensive tool for assessing the complete environmental profile of products, processes and services.

In addition to the range of studies with practical applications of LCA, also increasing approaches in order to discuss the theoretical panorama of LCA, as shown by Cabeza et al. (2014); Piekarski et al. (2013); Bribián, Usón and Scarpellini (2009); Benedetto and Klemes (2009); Roy et al. (2009); Tillman (2000). Such studies highlight the quality of implementation and the preoccupation with environmental aspects.

By increasing application of LCA in environmental industry scenario, realize the knowledge demand of the possibilities of LCA use, especially in the planning of environmental strategy that the company can adopt. Nowadays, the environmental issues is seen as part of the organization strategy, resulting in benefits on ecological side but also in economic and social scenario, even in an indirect way (ABREU; RADOS; FIGUEIREDO JÚNIOR, 2004).

Kobayashi (2005) says that a product may be discarded before the real end of its economic life cycle, by economic limitations of their functional characteristics, performance, or simply by not presenting more the aesthetic tendencies desired by the user, due changes and/or technological updating. 


\section{INDEPENDENT JOURNAL OF MANAGEMENT \& PRODUCTION (IJM\&P)}

http://www.ijmp.jor.br

v. 5, n. 3, June - September 2014

ISSN: 2236-269X

DOI: 10.14807/ijmp.v5i3.186

This highlights an unplanned use of resources and the necessity of management strategies establishment in which the use of tools, such as LCA, is an important way to planning, establishment and control processes, products and services.

In this context, this paper aims to present, by means of a theoretical discussion, the role of LCA on strategic planning definition of the organization. It also shows the enormous potential of the tool for decision making primarily in environmental aspects, but also as critical factor in the development of actions in competitive framework.

\section{CONCERN ABOUT THE ENVIRONMENT AND SUSTAINABLE PRODUCTION}

Society, market and search for a development in an orderly manner, encourage businesses to introduce sustainable practices in their systems, in order to attend the environmental needs.

The social, technological, legal and ideological changing agreement has influenced the companies regarding their mode of planning and action before the market (ABREU; RADOS; FIGUEIREDO JUNIOR, 2004). The companies must, in an entrepreneurial perspective, taking into account the use of tools in the incorporation of a sustainable concept for the productive process (PIEKARSKI, et al., 2013).

As part of the business structure, the environmental performance of a company is defined from the environmental strategy that the same adopts and the current market scenario (ABREU; RADOS; FIGUEIREDO JÚNIOR, 2004).

In this way, according to Piekarski et al. (2013), a broad overview of processes, strategic, enterprising and responsible must consider the entire load involved in the life cycle of the product or service, not just the environmental impact generated by the production process or even by the extraction of resources needed for its production.

According to Kobayashi (2005), tools that enable the emphasizing with environmental care has an important role in the establishment of relations between a company and its stakeholders. Moreover, nowadays, one of the most frequently used tools and complete is the Life Cycle Assessment (LCA) (BOCKEN et al., 2012). 


\section{INDEPENDENT JOURNAL OF MANAGEMENT \& PRODUCTION (IJM\&P)}

http://www.ijmp.jor.br

v. 5, n. 3, June - September 2014

ISSN: 2236-269X

DOI: $10.14807 / \mathrm{ijmp} . v 5 i 3.186$

\section{LIFE CYCLE ASSESSMENT (LCA)}

The incorporation of sustainable aspects in production systems can be guided by the use of management tools in order to reach a better planning and practice of production. LCA is a tool that allows to evaluate environmental impacts of a product, system or productive process, throughout its entire life cycle (HAMZI; LONDICHE; BOURMADA, 2008; PEHNT, 2005).

From LCA application is possible to identify potential environmental impacts and the hotspots (where are the greatest contributions to the impacts) in order to pointing effective changes in environmental impacts reduction (BRIBIÁN; USÓN; SCARPELLINI, 2009).

The first studies in respect of productive environmental profile appeared on the 1960's with the oil crisis and the concern with the use of natural resources. At the start of the studies did not show the complexity and enormous application that present today. These studies were called to other names, as analysis of the environmental profile, eco-balance, among others (ROY, et al., 2009; CABEZA, et al., 2014).

These studies have weakened in the coming years, but gained strength by around 1990 with the concern about the solid waste and the standardization of the methodology by the International Organization for Standardization (ISO).

Nowadays, LCA studies are guided by two standards, ISO 14040 (2006a), which dictates the principles and structure and ISO 14044 (2006b), the requirements and guidelines.

A study of LCA is composed by four interactive phases, as illustrated in Figure 1, where changes in later stages may result in changes to the previous ones and vice versa. 
INDEPENDENT JOURNAL OF MANAGEMENT \& PRODUCTION (IJM\&P)

http://www.ijmp.jor.br

v. 5, n. 3, June - September 2014

ISSN: 2236-269X

DOI: 10.14807/ijmp.v5i3.186

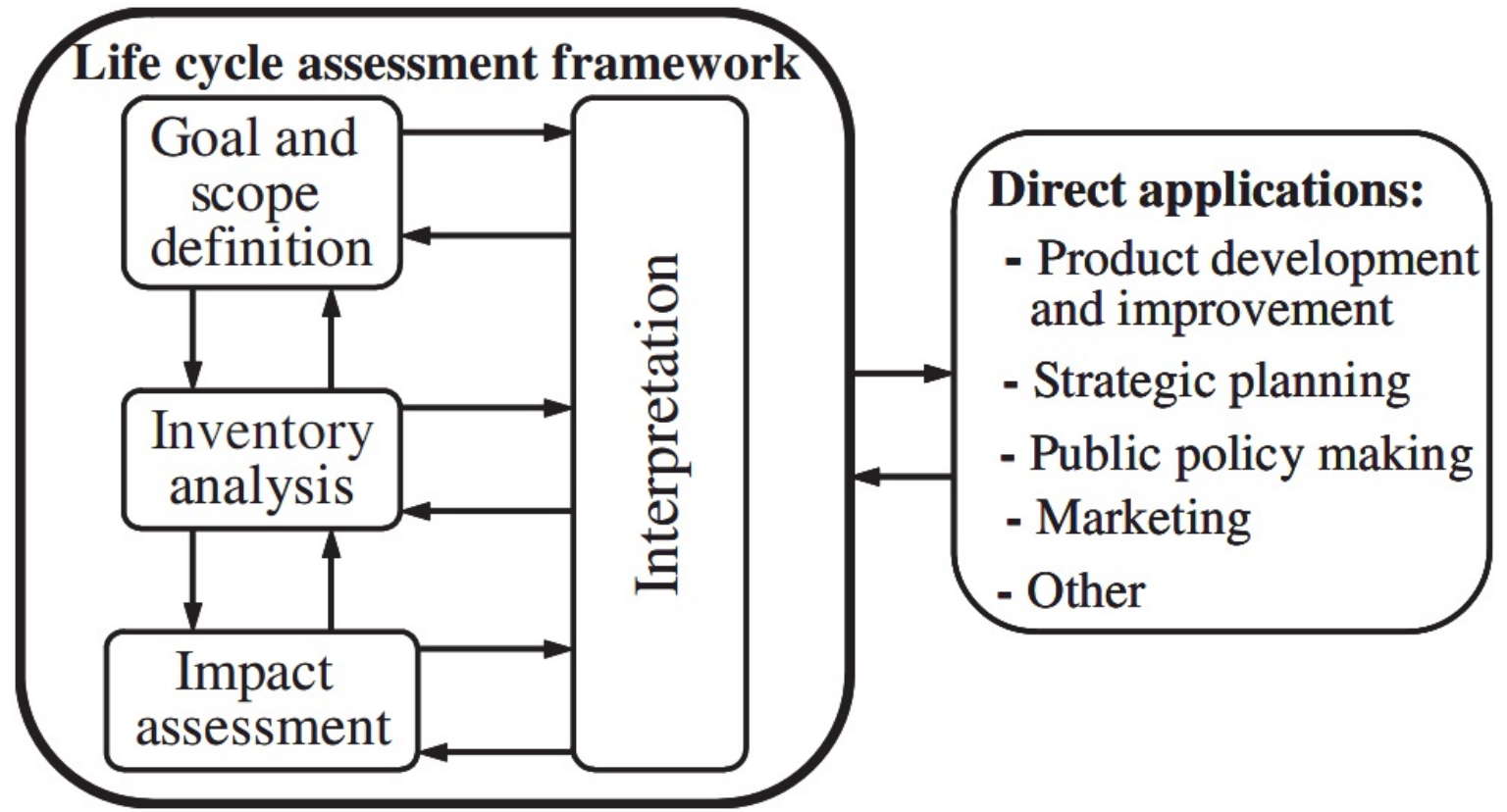

Figure 1 - Phases of an LCA and their relationships Source: ISO (2006a)

The first stage "Goal and Scope Definition" can be considered the most important component of an LCA for the reason that the study is carried out according to the declarations made in this stage.

\subsection{Definition of goal and scope}

In this phase are defined the system to be studied, their initial and final boundary, and the objectives to be achieved. There is, also, the adoption of the functional unit (portion to which all data are provided), in order to obtain a relationship between the data obtained and make possible comparisons between different LCA studies (BENEDETTO; KLEMES, 2009). Is also defined the indicators of category used and the categories of impact to be considered below.

\subsection{Life Cycle Inventory (LCl)}

The inventory step comprises the collection of data, of which all relating to inputs (water, raw materials, energy, etc.) and outputs (products, co-products, waste and emissions to air, water and soil) of the studied system (CABEZA, et al. , 2014).

According to Roy et al (2009), the collection of data may become less heavy if there is a basis for reliable data available, with data of generic processes, such as production of electric energy. 


\section{INDEPENDENT JOURNAL OF MANAGEMENT \& PRODUCTION (IJM\&P)}

http://www.ijmp.jor.br

v. 5, n. 3, June - September 2014

ISSN: 2236-269X

DOI: 10.14807/ijmp.v5i3.186

\subsection{Life Cycle Impact Assessment (LCIA)}

This phase of LCIA is the core of the study, where occurs the qualification and quantification of the impacts of the system, based on the indicators (i.e.: resource consumption, emissions) and categories of impact (i.e.: global warming potential, ozone layer depletion, eutrophication) previously proposed and in agreement with the data obtained in the phase of LCI (CABEZA, et al., 2014).

Tillman (2000) says that in this phase is held the allocation process, responsible for proportional distribution of the burden assigned to the system. When there is no ramification of the productive chain by the formation of co-products not considered in the study, for example.

\subsection{Life Cycle Interpretation}

The interpretation, the final step of a LCA, provides an overview of the conclusions, limitations and recommendations obtained in LCA study. It is from that occurs to decision-making by aligning the results found when planning the company in order to achieve the reduction of impacts identified.

For Basson and Pietre (2007), in different perspectives, the results of the LCA can serve as a basis for the decision-making process where, according to Roy et al. (2009), these guide the process of identifying the parties where improvements can be made and achieve better results.

\subsection{Main considerations of LCA tool}

The LCA toll can act in several fields. Have being responsible for environmental improvements in civil construction sectors (THIEL, et al., 2013), automotive industries (CHEN et al., 2012), pulp and paper industries (BOSS; BLOK; Patel, 2012), industry of coal (BAILIS, et al., 2013), of wood panels (BENETTO; BECKER; WELFRING, 2009) and many others.

Recently, the LCA has won recognition as a tool for measuring environmental performance both within the public sector as in private (BASSON; PETRIE, 2007). For Löfgren, Tillman and Rinde (2011) LCA is the more important methodology in current environmental management.

\section{ENVIRONMENTAL ISSUES ON ORGANIZATIONS}


INDEPENDENT JOURNAL OF MANAGEMENT \& PRODUCTION (IJM\&P)

http://www.ijmp.jor.br

v. 5, n. 3, June - September 2014

ISSN: 2236-269X

DOI: 10.14807/ijmp.v5i3.186

The environmental pressures has influence in performance and action approach of organizations. The environmental impact of production system, environmental legislation and the stakeholders are the main factors of influence in this approach of planning and action. Accordingly, the organization can identify its position regarding the environmental aspects of productive process and define its planning to draw prospects in environmental scenario (MURRAY, et al., 2006; PORTER, 1990).

In addition, it should be consider the difficulty faced by organizations in practice the theoretical baggage of ecological change, second Brandalise et al. (2009), taking ahead effective measures toward environmental improvement.

In this aspect, as well as the economic sphere, in a social context the community that involves the physical structure of the business can also influence on environmental performance results, once that actions affect the environment in the region bring consequences to economic and social spheres.

Abreu, Rados and Figueiredo Júnior (2004, p. 147) say "when the environmental requirements of the interested parties are effective, its interfere in the strategic decisions of organizations and can be considered as essential elements in the quest for sustainability".

In this panorama, Teixeira and Azevedo (2013) also disclose that, by either legislation order or other forces, the implementation of changes in order to adapt the organization management to new demands leads to a values change incompatible with current and future principles, "more durable".

To sustain the entire external load of influence, the company needs to find ways to evaluate its structure and adopt strategies to overcome its weaknesses and strengthen it, or even keep it in the market.

\section{OVERVIEW OF ENVIRONMENTAL ASSESSMENT MODELS}

In a general way, the models of performance evaluation does not take into account the environmental performance of the company. Abreu, Rados and Figueiredo Junior (2004) argue that the current models of analysis of structure takes into account only the financial aspect in determining the action profile and strategy of competitiveness. 
INDEPENDENT JOURNAL OF MANAGEMENT \& PRODUCTION (IJM\&P)

http://www.ijmp.jor.br

v. 5, n. 3, June - September 2014

ISSN: 2236-269X

DOI: 10.14807/ijmp.v5i3.186

Abreu, Rados and Figueiredo Junior (2004) propose a model of analysis of the structure in an environmental perspective, which is dependent on the context in which marketplace is inserted, once that environmental requirements are part of the profile of planning and strategy of the company.

The model Structure-Conduct-Performance (SCP) (SCHERER; ROSS, 1990) is based on a structure of supply and demand, taking into account "coincidences", which the authors called "external shocks", of which innovations, social and legal changes, that influence the strategy of the company.

Abreu (2001) considers a triple model, Triple Structure-Conduct-Performance (T-SCP), resulting in a performance that encompasses three pillars of the same importance: social, economic and environmental.

The model Environmental Structure-Conduct-Performance (E-SCP) (ABREU, 2001) provides a classification regarding the environmental performance of the company that is proportional to the development of the process of quantification of their own performance.

The company will have, then, a strong environmental conduct when carrying out the measurement of its environmental performance and consequently develops strategies in this field.

The model Pressure-State-Response (PSR) (OECD, 1998), from the environmental performance sculpts the priorities for action in order to achieve reduction of environmental impacts and conservation of natural resources integrated actions in individual and collective scope.

In order to evaluate the organization situation forward to panorama of environmental market, Abreu (2001) proposed a correlation matrix (Figure 2) between the industry pressure and the environmental conduct adopted. 
INDEPENDENT JOURNAL OF MANAGEMENT \& PRODUCTION (IJM\&P)

http://www.ijmp.jor.br

v. 5, n. 3, June - September 2014

ISSN: 2236-269X

DOI: 10.14807/ijmp.v5i3.186

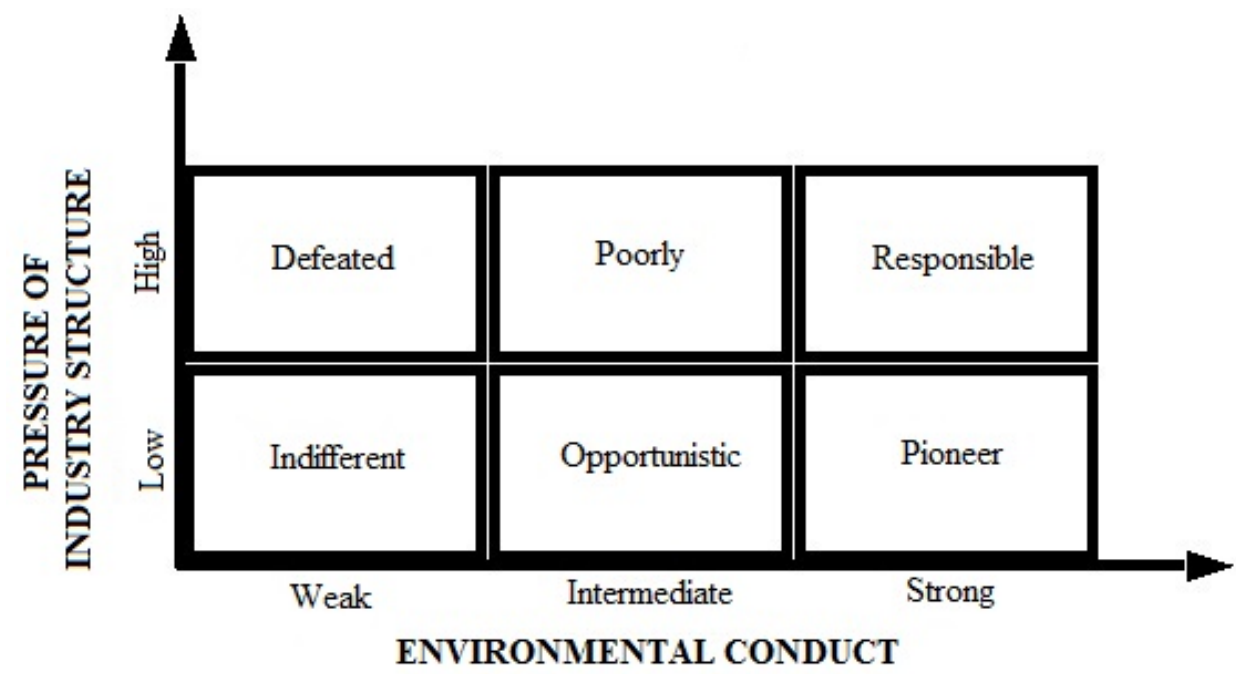

Figure 2 - Correlation matrix between the industry pressure and environmental conduct

Source: Abreu (2001)

The matrix analysis shows that if the environmental conduct is strong, the organization will suffer less external pressure, being considered at least as a environmental responsible company. If the company do not care about some environmental concern will be considered indifferent, being sufficient an increase in external pressure to become a defeated company.

Taking into account the concern with market pressures, the development of a strong general structure can determine the establishment and permanence of the company within the competitive scenario. In this regard, Basson and Pietre (2007, p. 168) affirm "a large number of choices of structure and parameters models are based on decision models and LCA".

As seen in the matrix of environmental structure of Abreu (2001), in Figure 2, the insouciance with the environmental conduct can make the company defeated. Likewise, in addition to the environmental aspects, the LCA can be used as an aid in the economic field and bring benefits in this regard.

\section{ECONOMY, COMPETITIVENESS AND LCA}

The interaction with external factors has influence in action mode of organizations. Each organization will present a specific performance, according to their ability to deal with externalities and their capacity to adapt (PORTER, 1980).

According to Abreu, Rados and Figueiredo (2004), the parameters that indicate the competitive potential of a company are primarily related to its basic 


\section{INDEPENDENT JOURNAL OF MANAGEMENT \& PRODUCTION (IJM\&P)}

http://www.ijmp.jor.br

v. 5, n. 3, June - September 2014

ISSN: 2236-269X

DOI: 10.14807/ijmp.v5i3.186

economic structure and also, but not only, with the mode and strategy action of its competitors. The same authors affirm that the development of strategies seeks to divert the company of consequences of their competitor actions, as well as achieve a superior performance.

Regarding decision making, is necessary to identify if decisions are in accordance with demand and values of stakeholders. As well as aligned same aspects of the organization in order to put the company ahead of the market (BASSON; PIETRE, 2007).

Thus, in the current global productive scenario, the development of strategies in environmental management can result in economic benefits and competitive within the market.

The LCA, in addition to obvious reduction in environmental impacts, can act in the processes improvement driving benefits of economic order or even indicating ways to obtain these, as for example reduction of energy consumption (MANDA; BLOK; PATEL, 2012) and improvement in overall efficiency of the process (BRIBIÁN; CAPILLA; USÓN, 2011), among others.

\section{LEGISLATION AND LCA}

In the view of Abreu, Rados and Figueiredo (2004), rigid regulations exert a greater influence on the activities of a company, rising the concern with the environmental aspects; otherwise, the attention given to this aspect is not very relevant. According to Porter (1980), a robust environmental legislation can lead to new practices, innovation, which can result in improvement of the factor of competitiveness of the company, bringing benefits to marketing, as discussed in the next section.

In the study of Abreu, Rados and Figueiredo (2004) can be noticed that the pressure exerted by the legislation in an industry is directly proportional to impact of activity that this industry performs.

In addition, was note that not only environmental protection agencies and inspection agencies are important in environmental actions making. The stakeholders, as in the study of Boss, Blok and Patel (2011), are often responsible 


\section{INDEPENDENT JOURNAL OF MANAGEMENT \& PRODUCTION (IJM\&P)}

http://www.ijmp.jor.br

v. 5, n. 3, June - September 2014

ISSN: 2236-269X

DOI: 10.14807/ijmp.v5i3.186

for encourage, or even require, the use of environmental policies for maintenance of trade relations.

Many customers may require the presence of environmental labeling and other actions in order to create, or maintenance, the business bond (CLIFT; WRIGHT, 2000).

Is possible understand, therefore, that the LCA may play an important role for the strategic management of a company in terms of the environment, supporting the management of productive activities and business relations.

\section{MARKETING AND LCA}

In optics of Piekarski et al. (2013), the LCA can be utilized as support to the overall planning of the company. LCA can used in the motivation of entrepreneurship, marketing strategies, in the assessment of new production systems and improving the performance of production processes, in addition to cooperate in the design and development of products.

Marketing strategies can derive the range of environmental labels, in which the LCA can aid in obtaining. In a broader vision, the environmental labelling, in addition to the compliance with the provisions imposed by legislation, can provide credibility to the company. Both in relation to consumers, as the suppliers and partners, the credibility coming for environmental labels is a positive aspect through the vision of sustainable involvement. Such practices are encouraged by market forces and interest of consumers (KOBAYASHI, 2005).

\section{INNOVATION AND LCA}

Furthermore, LCA can act on the innovation process and reduce environmental impacts (LUZ, 2011). With the identification of critical points, guided by innovation, new products, processes, or even new practices are responsible for reduction of their respective impacts, supplying sustainable and economic aspects and given the constraints of the market (PIEKARSKI, et al., 2013).

The innovation can be applied in the design of new products, processes, services, as well as on the improvement of already existing (OECD, 2005). On the other hand, LCA operates in environmental parameters by assigning characteristics ecologically cleaner to the products, processes and services. 


\section{INDEPENDENT JOURNAL OF MANAGEMENT \& PRODUCTION (IJM\&P)}

http://www.ijmp.jor.br

v. 5, n. 3, June - September 2014

ISSN: 2236-269X

DOI: 10.14807/ijmp.v5i3.186

Vinodh and Rathod (2010) claim to be possible linking environmental and economic requirements in the stages of development of a product. In this way, is noted the use of LCA indicators in order to reach the integration of different spheres of sustainable development to reduction of environmental impacts. The study of Luz (2011), in the construction of a model linking innovation and LCA, was identifying, through a statistical analysis, critical points of greater correlation between LCA and innovation indicators of decision-making support in reduction of impacts. This study allows, therefore, take into account environmental and economic aspects of the company, derived from innovative organization profile.

Kobayashi (2005) reveals that the characteristics, environmental requests and the user requirements do not always are aligned at the start of a product/process project. It is need that all these informations be in accordance with the values and company parameters. Also, is essential a plan that takes into account both the market demand, the result of the behavior and consumers desire, as well as the legislation that reigns the care with the environmental aspects.

\section{STRATEGIC DEVELOPMENT AND LCA}

In the quest for a sustainable development, Saints and Souza (2011) pointed out the Strategic Environmental Assessment (SEA) as one of the tools that plays an important role in the organization planning. Complementing, for Piekarski et al (2013), the economic and social development can be supported by entrepreneurial actions, including new tools that will assist in organization strategies.

In this sense, Pinto-Varela, Barbosa-Pódova and Novais (2011) worked on formulation of a programming model in order to take into account economic and environmental aspects, using LCA in combined form in the supply chain. Thus, evidencing once again, the concern with environmental aspects linked to productive systems, with LCA utilization on planning and strategy of the organization.

Basson and Pietre (2007) consider the use of LCA indicators as extreme value in the model formulation, as a guide for decision-making. For Piekarski et al. (2013) the use of sustainable tools in an entrepreneurial approach can be used in order to reach competitive advantages, supporting in the decision-making process, especially in the areas of processes and operations. 


\section{INDEPENDENT JOURNAL OF MANAGEMENT \& PRODUCTION (IJM\&P)}

http://www.ijmp.jor.br

v. 5, n. 3, June - September 2014

ISSN: 2236-269X

DOI: 10.14807/ijmp.v5i3.186

In search for sustainable practices in the industry, for Kobayashi (2005), the LCA has an important role as a tool for environmental planning, at different levels. This fact corroborates with the idea of Benedetto and Klemes (2009) about the use of methodologies of life cycle in different levels, which is demonstrate in Figure 3.

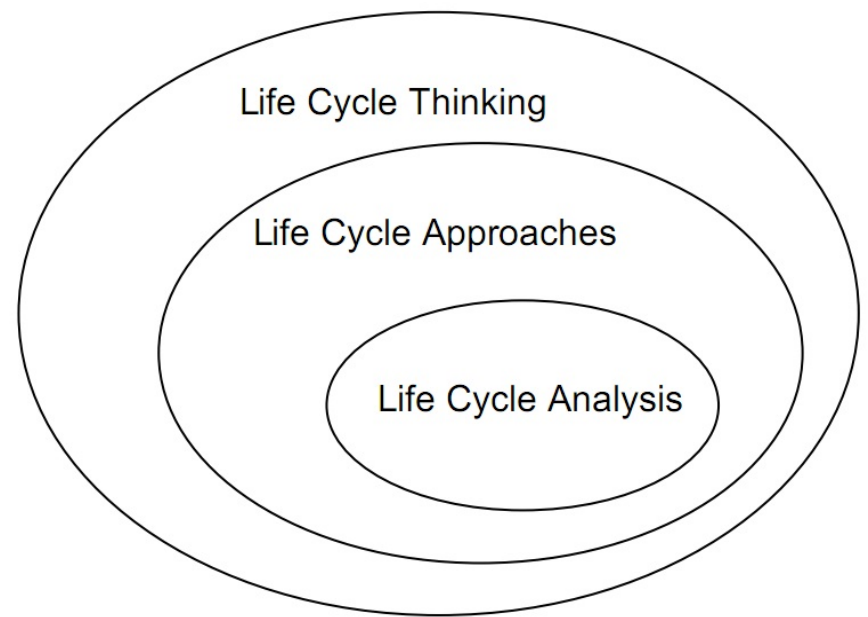

Figure 3 - Different levels of implementation of methodologies for life cycle Source: Benedetto and Klemes (2009)

Taking into account the entire life cycle of a product, the LCA provides a complete view of the panorama of environmental system under study (BOCKEN, et al, 2012). In the opinion of Roy et al. (2009), LCA is rapidly developing and becoming an important tool for the industry and the environmental sciences.

Furthermore, LCA can serve as an important information source, being a great assistance to processes and management in a company (PIEKARSKI, et al., 2013). Primarily as to decision-making under environmental scenario, in addition to acting in value generation for the organization, guiding process improvements, operations management and strategic planning.

Bribián, Capila and Usón (2011), in a comparative LCA study, evaluate the eco-efficiency of materials used in civil construction, between commonly materials and eco-materials. The results showed that the use of eco-innovation in order to substituting finite natural resources per raw materials derived from waste generated in other production processes, among other procedures, presents real capacity of impacts reduction and improving efficiency. Moreover, its encourage competition among manufacturers to achieve products more eco-efficient and the utilization of environmental declarations. It is evident different approaches resulting from LCA 


\section{INDEPENDENT JOURNAL OF MANAGEMENT \& PRODUCTION (IJM\&P)}

http://www.ijmp.jor.br

v. 5, n. 3, June - September 2014

ISSN: 2236-269X

DOI: 10.14807/ijmp.v5i3.186

application, guiding the impacts reduction on resources consumption and others factors of competitiveness.

The necessity to consider the social and environmental aspects in a productive process gains support by LCA, in the management of resources and waste, and to aid the development of strategic plans (PIEKARSKI, et al., 2013).

Based on a study of the analysis of uncertainties for decision-making, Basson and Petrie (2005) emphasize the importance and the differential use of LCA in decision-making based on environmental informations of the system.

Kobayashi (2005) says in a conscious environmentally business system, it is important to implement effective alternatives in life cycle, reusing components and modernizing of products. In this way, for Bocken et al. (2012), the LCA can give support to decision-makers regarding environmental characteristics of the process in strategies definition on sustainable basis. Thus, the LCA can be used as a tool for decision-making (BORGHI, et al., 2007; TILLMAN, 2000).

The LCA can assist in various aspects of planning and strategies definition throughout the production process. Moreover, LCA has applied in production, costumer relations and merchandising aspects. These latter aspects are able to provide benefits through results found by LCA, being useful for strategies formulation by decision-makers.

\section{EMPIRICAL FINDINGS SUPPORTING LCA FOR STRATEGY}

In order to cooperate with previously theoretical discussions, this section illustrate empirical findings of LCA application in different areas of business strategy.

At first, Chen et al. (2012) worked with evaluation of environmental sustainability through LCA. Was replaced the energy matrix of motor vehicles, changing fossil fuels use for hydrogen engines, given by renewable energy technologies. The technology change caused a decrease of greenhouse gas emissions resulting in environmental impact reduction. The environmental management of company studied has improved and was possible reach improvements in the social aspect. Moreover, the use of a new technology puts company ahead in the market by pioneering. 


\section{INDEPENDENT JOURNAL OF MANAGEMENT \& PRODUCTION (IJM\&P)}

http://www.ijmp.jor.br

v. 5, n. 3, June - September 2014

ISSN: 2236-269X

DOI: 10.14807/ijmp.v5i3.186

In a pulp and paper industry, was applied the LCA in a comparative way. Manda Blok and Patel (2012) compared new coatings and different types of cellulose with conventional process to assess the environmental impacts and possible gains in paper production. The study shows that after rearranging production strategy, with changes in technology process, was possible a reduction of around $10 \%$ of global environmental impacts compared to traditional process.

For a modular wooden playground, a LCA study was conducted by GonzalezGarcia et al. (2012) and from LCA results was opted for redesign the product. Changes were made in the areas of Research and Development, where occurred the substitution and reduction of raw materials and was optimized the supply chain through combined maritime and road way for transport and distribution.

In a coal industry, Bailis et al. (2013) conducted a comparison of the use of conventional furnaces and hot-tail kilns. By LCA, was possible to optimize environmental management of company, employing an unconventional technology (hot-tail kilns) which resulted in reducing impacts. Additionally, it was also achieved economic advantage for the reason that in conventional furnaces, the gases of pyrolysis for charcoal production is released directly into the atmosphere, as by the use of hot-tail kilns these gases are easily caught and can be used in power generation in other process steps.

Gutiérrez et al. (2012) conducted another LCA study in a lime industry. The study aimed to quantify the environmental impacts of lime production in an industry in Cuba through the LCA methodology in evaluating the cradle-to-gate. Also, was established a baseline for performance improvement by comparing the environmental impacts of industry in Cuba with a Swiss (industrialized country) plant. Empirical findings of this study revealed the possibility of improvements in process management and environmental management system. The most significant improvements in environmental performance and cost savings can be achieved by improving the energy efficiency in the calcining stage, which is partially achieved with moderate investments.

In sector of wood-based panels, Silva (2013) and David et al. (2009) point out environmental and social problems related to the emission of free formaldehyde, both during production and during use of panels. In this case, LCA guide the 


\section{INDEPENDENT JOURNAL OF MANAGEMENT \& PRODUCTION (IJM\&P)}

http://www.ijmp.jor.br

v. 5, n. 3, June - September 2014

ISSN: 2236-269X

DOI: 10.14807/ijmp.v5i3.186

establishment of cleaner or greener production strategies and review of regulatory aspects (or policy formulation), by the broad view that LCA can offer.

It is evident, therefore, that the empirical findings and possible simulations of LCA studies can guide processes improvements in addition to environmental, economic and social benefits (MANDA; BLOK; PATEL, 2012; BAILIS, et al., 2013). In this sense, LCA is able to guide the definition, management and implementation of sustainable strategies in different fields (BRIBIÁN; CAPILLA; USÓN, 2011).

\section{FINAL CONSIDERATIONS}

The increasing concern with environmental issues shows that the organizations require themselves (and due to external pressures) a conduct more sustainable. This fact implies in a best action planning thought on environmental standpoint, nevertheless not allowing affect the survival economic characteristics of organization.

In strategies definition, either short or long term, LCA shows as an important tool for company management. LCA can be responsible for guiding actions for the impacts reduction in the studied system, and may be used in accomplishment of legal requirements under environmental scenario.

The LCA can, also, be applied as a competitive advantage by means of possible environmental labelling, strategies definition in marketing, innovation and mainly in decision-making, encompassing all these issues. In a comprehensive manner, LCA plays as facilitator in decision-making,

Especially, the discussion of this paper provides to industrial scenario an enlightening overview of LCA applications possibilities in different spheres of sustainable development. With this, it can be observed advances for the organization, by the support in decision-making, as well for environment and, consequently, for society.

\section{ACKNOWLEDGMENTS}

The authors would like to thank the financial support under Fundação Araucária and CAPES/CNPq (National Council for Scientific and Technological Development). 
INDEPENDENT JOURNAL OF MANAGEMENT \& PRODUCTION (IJM\&P)

http://www.ijmp.jor.br

v. 5, n. 3, June - September 2014

ISSN: 2236-269X

DOI: 10.14807/ijmp.v5i3.186

\section{REFERENCES}

ABREU, M. C. S.; RADOS, G. J. V.; FIGUEIREDO JUNIOR, H. S. (2004) As pressões ambientais da estrutura na indústria. Revista de Administração de Empresas Eletrônica, v. 3, n. 2, p. 1-22.

BAILIS, R.; RUJANAVECH, C.; DWIVEDI, P.; VILELA, A. O.; CHANG, H.; DE MIRANDA, R. C. (2013) Innovation in charcoal production: A comparative life-cycle assessment of two kiln technologies in Brazil. Energy for sustainable development, v. 17 , n. 2, p. 189-200.

BASSON, L.; PETRIE, J. G. (2007) An integrated approach for the consideration of uncertainty in decision making supported by Life Cycle Assessment. Environmental Modelling \& Software, v. 22, p. 167-176.

BENETTO, E.; BECKER, M.; WELFRING, J. (2009) Life Cycle Assessment of Oriented Strand Boards (OSB): from Process Innovation to Ecodesign.

Environmental Science \& Technology, v. 43, n. 15, p.6003-6009.

BENEDETTO, L.; KLEMES, J. (2009) The Environmental Performance Strategy Map: an integrated LCA approach to support the strategic decision-making process. Journal of Cleaner Production, v. 17, p. 900-906.

BENETTO, E.; BECKER, M.; WELFRING, J. (2009). Life Cycle Assessment of Oriented Strand Boards (OSB): from Process Innovation to Ecodesign.

Environmental Science \& Technology, v. 43, n. 15, p.6003-6009.

BOCKEN, N. M. P.; ALWOOD, J. M.; WILLEY, A. R.; KING, J. M. H. (2012)

Development of a tool rapidly assessing the implementation difficulty and emissions benefits of innovations. Technovation, v. 32, p.19-31.

BRANDALISE, L. T.; BERTOLINI, G. R. F.; ROJO, C. A.; LEZANA, A. G. R.; POSSAMAI, O. (2009) A percepção me o comportamento ambiental dos universitários em relação ao grau de educação ambiental. Gestão da Produção, v. 16, n. 2, p. 273-285.

BRIBIÁN, I. Z.; CAPILLA, A. V.; USÓN, A. A. (2011) Lyfe Cycle Assessment of building materials: Comparative analysis of energy and environmental impacts and evaluation of the eco-efficiency improvement potential. Building and Environment, V. 46, p. $1133-1140$.

BRIBIÁN, I. Z.; USÓN, A. A.; SCARPELLINI, S. (2009) Life cycle assessment in buildings: State-of-the-art and simplified LCA methodology as a complement for building certification. Building and Environment, v. 44, p. 2510-2520.

CABEZA, L. F.; RINCÓN, L.; VILARIÑO, V.; PÉREZ, G.; CASTELL, A. (2014) Life cycle assessment (LCA) and life cycle energy analysis (LCEA) of buildings and the building sector: A review. Renewable and Sustainable Energy Reviews, v. 29, p. 394-416.

CAMBRIA, D.; PIERANGELI, D. (2012) Application of a life cycle assessment to walnut tree (Juglans regia L.) high quality wood production: a case study in southern Italy. Journal Of Cleaner Production, p. 37-46.

CHEN, I-C.; FUKUSHIMA, Y.; KIKUCHI, Y.; HIRAO, M. (2012) A graphical representation for consequential life cycle assessment of future technologies - Pat 2: 
INDEPENDENT JOURNAL OF MANAGEMENT \& PRODUCTION (IJM\&P)

http://www.ijmp.jor.br

v. 5, n. 3, June - September 2014

ISSN: 2236-269X

DOI: 10.14807/ijmp.v5i3.186

two case studies on choice of technologies and evaluation of technology

improvements. International Journal of Life Cycle Assessment, v. 17, p. 270-276.

CLIFT, R.; WRIGHT, L. (2000) Relationships Between Environmental Impacts and Added Value Along the Supply Chain. Technological Forecasting and Social

Change, v. 65, p. 281-295.

GONZÁLEZ-GARCÍA, S.; LOZANO, R. G.; BUYO, P.; PASCUAL, R. C.;

GABARRELL, X.; PONS, J. R.; M., M. T.; FEIJOO, G. (2012) Eco-innovation of a wooden based modular social playground: application of LCA and methodologies. Journal of Cleaner Production, v. 27, p 21-31.

GUTIÉRREZ, A. S.; CANAGHEM, J. V.; MARTÍNEZ, J. B.; VANDECASTEELE, C (2012) Evaluation of the environmental performance of lime production in Cuba. Journal Of Cleaner Production, 2012, p. 126-136.

HAMZI, R.; LONDICHE, H.; BOURMADA, N. (2008) Fire-LCA model for envoironmental decision-making. Chemical Engineering Research and Design, v. 86, p. 1161-1166.

INTERNATIONAL ORGANIZATION FOR STANDARDIZATION (ISO). ISO 14040: Environmental Management -Life Cycle Assessment - Principles and Framework. Geneva (Switzerland): European Standard, 2006a.

INTERNATIONAL ORGANIZATION FOR STANDARDIZATION (ISO). ISO 14044:

Environmental management - life cycle assessment - Requirements and Guidelines. Geneva (Switzerland): European Standard, 2006b.

DAVID, J. K.;PETROVICI, V.; ZELENIUC, O.; BADESCU, A. L.; URDEA, S. M.; SANGEORZAN, L. (2009) Distribution of formaldehyde emission in particleboards. In: WSEAS International Conference on System Science and Simulation in Engineering, 8, Genova, Proceedings...Italy: WSEAS, 2009.

KOBAYASHI, H. (2005) Strategic evolution of eco-products: a product life cycle planning methodology. Research in Engineering Design, v. 16, p. 1-16.

LÖFGREN, B., TILLMAN, A., RINDE, B. (2011) Manufacturing actor's LCA. Journal of Cleaner Production, v. 19, p. 2025- 2033.

LUZ, L. M. (2011) Proposta de modelo para avaliar a contribuição dos indicadores obtidos na análise do ciclo de vida sobre a geração de inovação na indústria. Dissertation (Master in Production Engineering). Ponta Grossa: UTFPR, Available:

http://www.pg.utfpr.edu.br/dirppg/ppgep/dissertacoes/defesas.php?ano=2011\&grupo $=0$. Access: 08/01/2014.

MANDA, B. M. K.; BLOK, K.; PATEL, M. K. (2012) Innovations in papermaking: An LCA of printing and writing paper from conventional and high yield pulp. Science of the Total Environment, v. 439, p. 307-320.

ORGANISATION for Economic Co-Operation and Development - OECD (1998)

Towards Sustainable Development: Environmental Indicators. Paris: OECD, 1998.

PEHNT, M. (2006) Dynamic life cycle assessment (LCA) of renwable energy technologies. Renewable Energy, v. 31, p. 55-71.

PIEKARSKI, C. M. (2013) Proposta de melhoria do desempenho ambiental assoaciado ao ciclo de vida da produção de madeira MDF. 2013. 148 f.

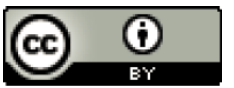

[http://creativecommons.org/licenses/by/3.0/us/]

Licensed under a Creative Commons Attribution 3.0 United States License 
INDEPENDENT JOURNAL OF MANAGEMENT \& PRODUCTION (IJM\&P)

http://www.ijmp.jor.br

v. 5, n. 3, June - September 2014

ISSN: 2236-269X

DOI: 10.14807/ijmp.v5i3.186

Dissertation (Master in Production Engineering). Ponta Grossa: UTFPR, Available: http://www.pg.utfpr.edu.br/dirppg/ppgep/dissertacoes/defesas. php?ano=2013\&grupo $=0$. Acess: 08/01/2014.

PIEKARSKI, C. M.; LUZ, L. M.; ZOCCHE, L.; FRANCISCO, A. C. (2013) Life Cicle Assessment as Entrepeneurial tool for Business Management and Green Innovations. Journal of Technology Management and Innovation, v. 8, n. 1, 2013, p. 44-53.

PINTO-VARELA, T.; BARBOSA-PÓDOVA, A. P. F. D.; NOVAIS; A. Q. (2011) Biobjective optimization approach to the design and planning of supply chains: Economic versus environmental performances. Computers and Chemical Engineering, n. 35, p. 1454-1468.

RIVELA, B.; MOREIRA, M. T.; FEIJOO, G. (2007). Life Cycle Inventory of Medium Density Fibreboard. International Journal of Life Cycle Assessment, v. 12, n.3, p.143-150.

ROY, P.; NEI, D.; ORIKASA, T.; XU, Q.; OKADOME, H.; NAKAMURA, N.; SHIINA, T. (2009) A review of life cycle assessment (LCA) on some food products. Journal of Food Engineering, n. 90, v. 1, p. 1-10.

SANTOS, S. M.; SOUZA, M. P. (2011) Análise das contribuições potenciais da Avaliação Ambiental Estratégica ao Plano Energético Brasileiro. Engenharia Sanitária e Ambiental, v. 16, n. 4, p. 369-378.

SANTOS, L. J. C.; TENÓRIO, J. A. S. (2010). Avaliação do ciclo de vida e custeio do ciclo de vida de evaporadores para usinas de açúcar. Revista Escola de Minas, p. 179-184.

Silva, D. (2013) Urea Formaldehyde resin: Impacts on the productive life cycle of wood based panel. In: CILCA, Mendonza. Proceedings... Mendonza: 2002.

TEIXEIRA, M. G. C.; AZEVEDO, L. P. (2013) A agenda ambiental pública: Barreiras párea articulação entre critérios de sustentabilidade e as novas diretrizes da administração pública federal brasileira. Revista Eletrônica de Administração, v. 19, n. 1, p. 139-164.

THIEL, C. L.; CAMPION, N.; LANDIS, AMY E.; JONES, A. K.; SCHAEFER, L. A.; BILEC, M. M.. A. (2013) Materials Life Cycle Assessment of a Net-Zero Building. Energies v. 6, p.1125-1141.

TILLMAN, A.. Significance of decision-making for LCA methodology. Environmental Impact Assessment Review, v. 20, 2000, p. 113-123.

USÓN, A. A.; CAPILLA, A. V., BRIBIÁN, I. Z.; SCARPELLINI, S.; SASTRESA, E. L. (2011) Energy efficiency in transport and mobility from an eco-efficiency viewpoint. Energy, v. 36, p. 1916-1923.

VINODH, S., R., G. (2010) Integration of ECQFD and LCA for sustainable product design. Journal of Cleaner Production, v. 18, n. 8, p. 833-842. 